\title{
The bioenergetic signature of cancer
}

\author{
José M Cuezva \\ From 16th International Charles Heidelberger Symposium on Cancer Research \\ Coimbra, Portugal. 26-28 September 2010
}

Cancer is a heterogeneous and complex genetic disease. In addition to genetic mutations in oncogenes and tumour suppressors, the onset and progression of cancer is also bound to the cancer cell's microenvironment. After many years of ostracism the energetic metabolism of cancer [1] has been accepted as an additional hallmark of the cancer phenotype [2] and mitochondrial/ glycolytic studies have spurred in the field. In this regard, it has been reported that the relative expression of $\beta$-F1-ATPase, which is the catalytic subunit of the mitochondrial $\mathrm{H}^{+}$-ATP synthase and thus a rate-limiting component of mitochondrial oxidative phosphorylation, is significantly diminished in human tumours when compared to its expression in normal tissues [2]. The down-regulation of $\beta$-F1-ATPase is accompanied by an increased expression of GAPDH, a marker of glycolysis. The tumour drop in the $\beta$-F1-ATPase/GAPDH ratio, that defines the "bioenergetic signature" of the cell [3], is a phenotypic trait fulfilled by more than $95 \%$ of the carcinomas analyzed in large cohorts of breast, colon and lung cancer patients [2]. These findings support a deficit in the overall bioenergetic activity of mitochondria in cancer. The quantification of the bioenergetic signature in different human carcinomas revealed that, irrespective of the cancer type, energy metabolism has a unique protein signature [4], thus providing a generic marker of the cancer cell that might be exploited in the combat of the disease [2]. The bioenergetic signature also has clinical relevance as an indicator of disease progression and as a predictive marker of the cellular response to chemotherapy [2]. Moreover, the bioenergetic signature affords a gauge of the glycolytic activity of the tumours, supporting that an altered oxidative phosphorylation is one of the determinants that underlies the abnormal aerobic glycolysis of the cancer cell [5].

Correspondence: jmcuezva@cbm.uam.es

Centro de Biología Molecular Severo Ochoa CSIC-UAM and CIBER de Enfermedades Raras (CIBERER), ISCIII, Universidad Autónoma de Madrid, Madrid, Spain
The specific repression of $\beta$-F1-ATPase mRNA translation partially explains the abnormal bioenergetic activity of mitochondria in colon, lung and breast tumours [6] as well as in hepatocarcinomas [7]. By manipulation of the bioenergetic signature in cancer cells we have documented that tumour promotion inevitably requires the selection of cells with a repressed bioenergetic activity of mitochondria [8]. In others words, cancer cells with a functional bioenergetic activity of mitochondria are unable to promote tumour development. In this presentation, I will summarize some of the findings that stress that cancer progression requires the silencing of the bioenergetic activity of mitochondria, emphasize its potential value for translation to the bed-side and discuss some of the strategies that we are developing aimed at identifying the players that participate in the regulation of the bioenergetic signature of the cancer cell.

Published: 24 September 2010

\section{References}

1. Warburg O: On respiratory impairment in cancer cells. Science 1956, 124:269-270.

2. Cuezva JM, Ortega AD, Willers I, Sánchez-Cenizo L, Aldea M, SánchezAragó M: The tumor suppressor function of mitochondria: Translation into the clinics. Biochim Biophys Acta 2009, 1792:1145-1158.

3. Cuezva JM, Krajewska M, de Heredia ML, Krajewski S, Santamaría G, Kim H, Zapata JM, Marusawa H, Chamorro M, Reed JC: The bioenergetic signature of cancer: a marker of tumor progression. Cancer Res 2002, 62:6674-6681.

4. Acebo $P$, Giner D, Calvo P, Blanco-Rivero A, Ortega AD, Fernández PL, Roncador G, Fernández-Malavé E, Chamorro M, Cuezva JM: Cancer abolishes the tissue type-specific differences in the phenotype of energetic metabolism. Transl Oncol 2009, 2:138-145.

5. López-Ríos F, Sánchez-Aragó M, García-García E, Ortega AD, Berrendero JR, Pozo-Rodríguez F, López-Encuentra A, Ballestín C, Cuezva JM: Loss of the mitochondrial bioenergetic capacity underlies the glucose avidity of carcinomas. Cancer Res 2007, 67:9013-9017.

6. Willers IM, Isidoro A, Ortega AD, Fernández PL, Cuezva JM: Selective inhibition of $\beta$-F1-ATPase mRNA translation in human tumours. Biochem J 2010, 426:319-326.

7. de Heredia ML, Izquierdo JM, Cuezva JM: A conserved mechanism for controlling the translation of $\beta$-F1-ATPase mRNA between the fetal liver and cancer cells. J Biol Chem 2000, 275:7430-7437. 
8. Sánchez-Aragó M, Chamorro M, Cuezva JM: Selection of cancer cells with repressed mitochondria triggers colon cancer progression. Carcinogenesis 2010, 31:567-576.

doi:10.1158/0008-5472.CAN-07-1678

Cite this article as: Cuezva: The bioenergetic signature of cancer. BMC Proceedings 2010 4(Suppl 2):O7.

Submit your next manuscript to BioMed Central and take full advantage of:

- Convenient online submission

- Thorough peer review

- No space constraints or color figure charges

- Immediate publication on acceptance

- Inclusion in PubMed, CAS, Scopus and Google Scholar

- Research which is freely available for redistribution

Submit your manuscript at www.biomedcentral.com/submit 